\title{
The Strategy Project: Teaching Strategic Thinking through Crisis Simulation
}

Michael A. Hunzeker, Princeton University

Kristen A. Harkness, University of St. Andrews

ABSTRACT In an effort to teach strategic thinking, the Center for International Security Studies at Princeton University designed an adaptable model for crisis simulation that could be used in a variety of institutional contexts and with diverse content matter. Moreover, the simulation helped students to develop an understanding of several other important abstract concepts in political science: notably, information uncertainty, friction or "the fog of war," and bureaucratic stove piping. This article describes the design, content, and implementation of our original simulation. It is based on a "loose-nukes" scenario resulting from the hypothetical collapse of the Pakistani state. We conclude by evaluating the benefits and limitations of the simulation and by suggesting ways in which it could be implemented in other institutional contexts.

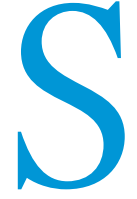

trategy is central to politics. Wars, elections, treaties, negotiations, and other outcomes we substantively care about depend on on the strategies that actors adopt to pursue their interests. Strategy is also one of the few political science concepts with widespread utility outside of the classroom. Students who grasp what it means to act, compete, and cooperate strategically will have a decisive edge in the war room, boardroom, or courtroom.

Unfortunately, teachers who want to expose students to this critical way of thinking have few effective tools at their disposal. This is especially true at the undergraduate level. From Clausewitz to Schelling, the canonical literature on strategy centers on abstract concepts and game-theoretic principles that are difficult for students to grasp. Even contemporary national-security strategy documents are a poor model for how to think strategically. Rather than focusing on dynamic tactics, they tend to read like "laundry lists" of goals and objectives. This overlooks the most important aspect of any strategic interaction: that is, the other side also has a say in the outcome.

Crisis simulations provide a better pedagogical tool for teaching students about strategy, strategic interactions, and strategic competition. Studies suggest that simulation exercises improve learning outcomes by grounding abstract concepts in concrete experience and allowing students to gain understanding of them through both active experimentation and problem solving. ${ }^{1}$ Moreover, unlike lectures and small-group discussions, simulations can be purposefully designed to induce real strategic interaction.

In 2011, in an effort to teach strategic thinking, the Center for International Security Studies (CISS) at Princeton University-as

Michael A. Hunzeker is a postdoctoral fellow and lecturer in politics and public policy at the Woodrow Wilson School, Princeton University. He can be reached at hunzeker@princeton.edu.

Kristin A. Harkness is a lecturer in the School of International Relations at the

University of St. Andrews. She can be reached at kh81@st-andrews.ac.uk. part of its broader Strategic Education Initiative (SEI)-designed an adaptable model for crisis simulation that could be used in a variety of institutional contexts and with diverse content matter. ${ }^{2}$ The simulation helps students to develop a conceptual understanding of several important abstract concepts in political science: notably, information uncertainty, friction or "the fog of war," and bureaucratic pathologies such as stove piping.

This article describes the design, content, and implementation of our original simulation, which was based on a scenario of missing nuclear material resulting from the collapse of the Pakistani state. We conclude by evaluating the benefits and limitations of the simulation and by suggesting ways in which it could be implemented in other institutional contexts.

\section{LEARNING OBJECTIVES AND CORRESPONDING DESIGN ELEMENTS}

Our primary goal was to construct a simulation that forced participants to compete and cooperate strategically. Beyond setting objectives, we wanted players to pursue their interests by developing plans and taking actions while coping with the dynamically changing tactics of other players, who were simultaneously pursuing their own discrete interests. In other words, we wanted players to interact with one another rather than "gaming" the rules of the simulation, which happens all too often when clear point systems or pay-off structures are adopted. Instead, the simulation is centered on a volunteer "control cell" that is charged with managing the game flow, enforcing rules, adjudicating moves, and controlling the states and actors not represented by the country teams. Of particular importance, the control cell began with a clear plan for how a terrorist organization would try to remove captured nuclear warheads from Pakistan (with several contingency plans), which allowed for flexible difficulty in "solving" the game. This design had the additional benefit of helping students to develop a conceptual understanding of the "fog of war" by permitting the 


\section{Figure 1}

\section{Simulation Structure}
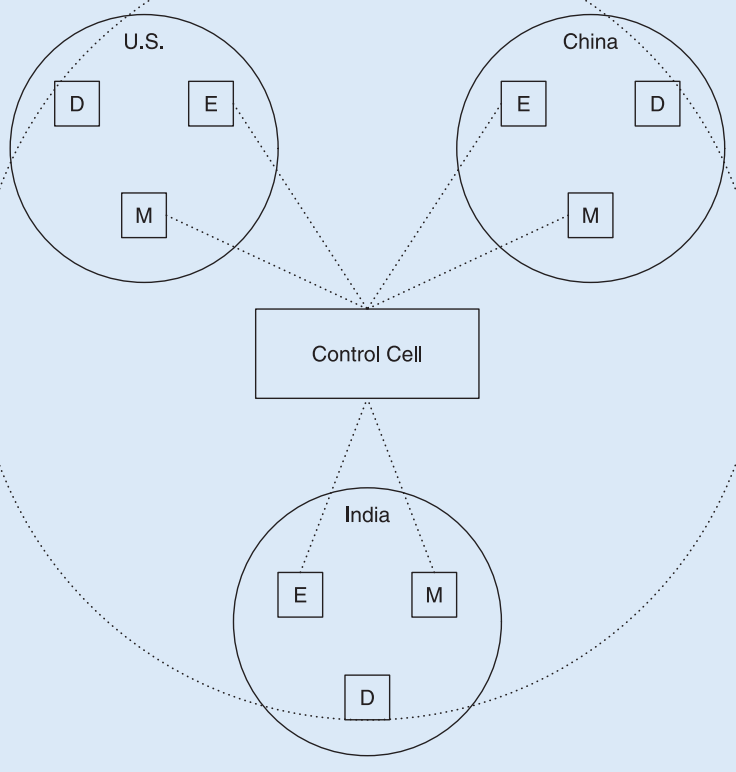

control team to inject uncertainty and unexpected events throughout the simulation.

A secondary objective was to introduce students to the challenges of bureaucratic politics and diplomacy that are also difficult to grasp abstractly. Because the problems encountered by large organizations-here, stove piping and information leakages-are difficult to replicate in a small-group setting, special design elements and artificial constraints on communication were imposed. After dividing student participants into country teams, they were further divided into three country cells: the chief executive, the military, and the diplomatic corps (figure 1). Each country cell was assigned to a separate room, forbidden from entering any other cell's room, and proactively —not only for their executive cell's current strategy but also for contingency strategies as other players' actions foiled their best-laid plans. This task was rendered even more difficult by the requirement of conforming to deployment realities. Each military cell was given a large packet of information detailing its available units (table 1) and how long it takes each type of unit to mobilize, travel, and unload (table 2). Preprinted forms were used to prompt each military cell to provide the correct information (table 3); tutoring by the control cell was necessary in the first few rounds because poor plans inevitably were submitted.

\section{THE SIMULATION}

\section{Logistics}

CISS opened participation in the Pakistan Crisis Simulation to any student at Princeton University. Because the simulation was not embedded in a course or set of courses, we required no advanced preparation. Advertisements were placed in several campus outlets prior to the simulation and because participant counts and team assignments were needed in advance, participants were asked to sign up via e-mail. Beyond attracting a large group of highly motivated students, such open enrollment had the additional advantage of serving as a recruitment mechanism for students who otherwise might not take a political science or security studies course. We had approximately 45 participants: a combination of undergraduates, master's degree students, and PhD candidates.

The simulation, which was held on a Saturday to accommodate as many students as possible, lasted approximately 8.5 hours. We dedicated the first hour to briefing participants on the simulation's rules, roles, and structure and to an initial team-planning session, in which the entire country team could meet together in a private room. Participants were given a prepared packet that included the simulation rules and scenario as well as a description of their country team's interests and the specific threats they were facing. Members of the military cells were given an additional packet that contained force structures and deployment timetables. A half-hour was allowed for a catered lunch break. The last hour was reserved for an extended debriefing in which the control cell summarized how events had

\section{Beyond attracting a large group of highly motivated students, such open enrollment had the additional advantage of serving as a recruitment mechanism for students who otherwise might not take a political science or security studies course.}

allowed to record and deliver orders only using carbon copy paper. The executive and military teams were further restricted to permitting only one cell member to leave the room at a time. Therefore, all diplomatic negotiations and interagency coordination had to take place in the public hallway, where it might be overheard. Coordination among country cells became difficult, which created a real risk of subunits pursuing isolated agendas that failed to create a coherent team strategy.

Our final objective was to introduce students to the realities of military planning, deployment, and civil-military relations. Although executive cells had the exclusive right to take action, any use of troops required extensive preplanning by the military cell. Executive cells could implement orders only for plans that their military cells had already filed with the control cell. Thus, military cells had to plan developed over the course of the day and then described the final outcome. A group discussion followed about what students had learned and how their acquired knowledge related to political science concepts and real-world crisis management.

We required one large lecture hall in which to conduct the briefing and debriefing sessions-the control cell also operated from this space-and enough smaller classrooms to accommodate each country cell, as well as a "media room" in which to update team representatives on developments. We provided each country cell with basic supplies, including pens, post-it notes, rulers, carbon copy paper, and stacks of any required forms. Each country cell and the control cell had a large map of Pakistan showing major roads, ports, cities, and other geographical features. The baseline costs of the simulation were minimal: supplies and facility fees totaled approximately \$250. 
Table 1

\begin{tabular}{|c|c|c|c|c|c|}
\hline LOCATION & AFGHANISTAN (KABUL) & OKINAWA & HAWAII & SAN DIEGO & INDIAN OCEAN \\
\hline Miles to Pakistani Border & 150 & 3,000 & 9,000 & 7,500 & 100 \\
\hline Special Operations Teams & 50 & 25 & 25 & 25 & 5 \\
\hline Infantry Divisions & 2 & 1 & 1 & 2 & 0.1 (expeditionary \\
\hline Cargo Aircraft & 100 & 100 & 25 & 200 & \\
\hline Transport Helicopters & 200 & 50 & 50 & 50 & 10 \\
\hline
\end{tabular}

Table 2

\section{Excerpt from Military Assets, Capabilities, and Movement Constraints}

\begin{tabular}{|c|c|c|c|c|c|}
\hline TYPE OF ASSET & COMPOSITION & CAPABILITY OR PURPOSE & TIME TO MOBILIZE & TIME TO TRAVEL & TIME TO OFFLOAD \\
\hline Special Operations Team & -10 troops per team & $\begin{array}{l}\text {-Surveillance and targeting } \\
\text {-Direct action } \\
\text {-Can be inserted via air, land, or sea }\end{array}$ & None & $\begin{array}{l}\text { Foot: } 5 \mathrm{mph} \\
\text { Vehicle: } 20 \mathrm{mph}\end{array}$ & None \\
\hline Infantry Company & $\begin{array}{l}-200 \text { troops } \\
-4 \text { platoons }\end{array}$ & $\begin{array}{l}\text {-Lightly armed } \\
\text { (rifles, machine guns, and mortars) }\end{array}$ & 3 hours & $\begin{array}{l}\text { Foot: } 3 \mathrm{mph} \\
\text { Vehicle: } 20 \mathrm{mph}\end{array}$ & 3 hours \\
\hline Infantry Battalion & $\begin{array}{l}-1,000 \text { troops } \\
-5 \text { companies }\end{array}$ & $\begin{array}{l}\text {-Lightly armed } \\
\text { (rifles, machine, guns and mortars) }\end{array}$ & 6 hours & $\begin{array}{l}\text { Foot: } 3 \mathrm{mph} \\
\text { Vehicle: } 20 \mathrm{mph}\end{array}$ & 6 hours \\
\hline Infantry Brigade & $\begin{array}{l}-5,000 \text { troops } \\
-5 \text { battalions }\end{array}$ & -Heavily armed (1 battalion artillery) & 24 hours & $\begin{array}{l}\text { Foot: } 3 \mathrm{mph} \\
\text { Vehicle: } 10 \mathrm{mph}\end{array}$ & 24 hours \\
\hline
\end{tabular}

Table 3

\section{Sample Military Planning Order (India team)}

\begin{tabular}{ll} 
Who & Infantry platoon from Northern Kashmir \\
\hline Where & Border crossing near Pakistani town of Kasur \\
\hline What/Why & Setup checkpoint on the road at the border crossing to search vehicles \\
\hline How & Transport by vehicle from Northern Kashmir \\
\hline When & $3 \mathrm{hrs}$ mobilization $+7.5 \mathrm{hrs}$ travel $(150 \mathrm{mi} / 20 \mathrm{mph})+1 \mathrm{hr}$ offload $=11.5 \mathrm{hrs}$
\end{tabular}

the previous round's set of orders and then brief participants in the media room. Teams could submit plans and orders at any time (but they would not be implemented until the end of each round), and they were encouraged to continue strategizing and planning during the breaks. Each 30-minute round represented 24 hours of "real-world" time: that is, round one began at noon on the first day of the crisis, round two at noon on the second day, and so on. This was vital for military planning purposes.
Lunch and travel expenses for outside professional experts (whom we embedded in the country cells as advisors) totaled an additional $\$ 5,000$, although both of these costs are optional.

\section{The Basic Structure}

Participants were randomly divided into country teams representing the United States, India, and Pakistan. As previously discussed, each countryteam was then further divided into executive, military, and diplomatic cells (see figure 1). More country teams can be added (e.g., Russia or Iran) and the number of participants in each cell is flexible to accommodate variance in participation rates. A professional expert was embedded in each country cell to serve as an advisor to the participants as well as to provide a "fly-on-thewall" perspective to help us understand the learning processes and difficulties of the simulation. 3 We also relied on a team of about 10 student volunteers, both graduate and undergraduate, to run the control cell. 4

The six hours of simulation play was divided into 30 -minute rounds followed by 15-minute "breaks" for the control cell to resolve
Each country cell had a defined set of responsibilities, as follows:

- Executive cells were charged with developing the primary goals and strategies for their country team, deciding which actions to take, and submitting official orders to the control cell (see table 3). They were given tremendous latitude in the types of military actions they could order-from prestaging ground forces to holding parades to conducting aerial reconnaissance to carrying out top-secret special-forces missions-as long as they conformed to their actual military capabilities and implemented only those plans already submitted to the control cell by their military. Executive cells also could implement nonmilitary actions without restriction, including holding press conferences, issuing condemnatory statements, and mobilizing human rights organizations.

- Military cells were responsible for proactively developing plans in line with their country's strategic goals and filing copies with the control cell. This responsibility, by far, was the most procedurally difficult. Not only did the military cells have to anticipate their country's strategic needs; they also had 
to operationalize those strategies by calculating mobilization, travel, and off-loading schedules in real time and then translating this information into game-play time (see table 3 ). Furthermore, included in the packet of information describing their own capabilities, military cells also received partial information on the assets of other teams, which provided insight into their potential strategies. Military cells were encouraged to triplicate their plans (using the carbon copy paper): submitting one copy to the control cell, keeping one copy, and giving the third copy to their executive cell. Finally, military cells were allowed to submit reasonable intelligence requests to the control cell (which decided whether to respond).

- Members of the diplomatic cells were the only participants allowed to negotiate with other country teams. Although it was a seemingly minor ability, this gave diplomats the power to achieve their country's interests via cooperation or deception. They could make any agreement they so desired-but were forewarned that other countries, as well as their own, were free to ignore those agreements.

One of this structure's most useful aspects is its flexibility; it can support virtually any crisis scenario. Therefore, the substantive content of the simulation can be modified to teach specific concepts or to reflect current international events. same time, all participants were given background information (in their simulation packets) about each country's long-term interests in the region and their resulting potential to exploit the situation.

\section{EVALUATION}

\section{Outcome}

After approximately six rounds of play, the simulation ended with two major developments. First, a combined task force of specialoperations units from all three countries successfully located and intercepted the two warheads just as they were about to cross the Pakistani border. Second, India and China inadvertently started a war. By far, this unintended conflict was the most interesting and "teachable" outcome because it resulted from a combination of mutual mistrust (i.e., a security dilemma) and bureaucratic processes gone awry (i.e., stove piping). Neither India nor China could reassure the other that they would not use the crisis to redress their long-standing border dispute. Ultimately, both countries defensively moved troops into the contested zone.

This action alone would not have led to conflict were it not for the bureaucracies run amok. By the midpoint of the simulation exercise, the military cells of both India and China became adept at rapidly churning out military plans because both felt quantity would best meet future changes in strategy. They also began building

\section{One of this structure's most useful aspects is its flexibility; it can support virtually any crisis sce- nario. Therefore, the substantive content of the simulation can be modified to teach specific con- cepts or to reflect current international events.}

\section{The Crisis Scenario}

In the morning briefing session, participants were told that the Pakistani judiciary had launched an investigation of Pakistan's Inter-Services Intelligence (ISI) agency two weeks prior. In response, the ISI pressured the civilian government to obstruct the judiciary on national-security grounds. The fragile parliamentary coalition acquiesced, leading to widespread protests and the defection of several coalition parties as well as triggering the collapse of the civilian government. Protests then turned violent, fracturing along ethnic lines. Because of the increasing chaos, the Pakistani Army had staged a coup to restore order. During the struggle for power among factions of the officer corps, as-of-yet-unidentified extremists gained control over one or more nuclear warheads-likely through known sympathizers in the ISI. The simulation begins with the news that intelligence sources suspect that the extremists will attempt to smuggle the warheads out of Pakistan and sell them to other terrorists.

This scenario compelled participants to balance competing strategic interests: namely, the need for country teams to cooperate to find the missing nuclear materials against each country's desire to prevent others from exploiting the chaos. This had to happen while potentially leveraging the situation to achieve each country's own long-standing interests in the region. To maximize incentives for cooperation, each country was given information about a real terrorist group that had targeted them in the past, that had ties to Pakistan, and that could gain control over the nuclear material. Thus, at least in the beginning, all three teams shared an equal interest in preventing the warheads from leaving Pakistan. At the contingency into their orders in the form of if-then statements: for example, if the troops encounter no resistance when they arrive at point $\mathrm{Z}$, then they start patrolling, but if they encounter an enemy unit, then they fire. In terms of bureaucratic efficiency, this approach worked extremely well. Military cells could cover multiple potential scenarios in a single planning document and preplan for a vast range of strategic needs. In terms of efficacy, it was a complete disaster. The sheer volume of military planning overwhelmed the executive cells, which began skimming their copies of the military plans. In the last round, the executive cells of both China and India thought they had merely ordered troops into the border zone. However, those orders contained if-then statements that required them to engage if they encountered foreign troops. When both countries moved units into the same geographical space-that is, when they made contact with one another-they automatically began a firefight. The initial bloodshed activated other contingency plans that, in turn, led to an inadvertent war. Thus, a mutual attempt to deter war ultimately caused one.

\section{Benefits}

We found that this unique model for crisis simulation has three major strengths. First and most important, it is an effective way to teach students about the dynamic nature of strategic interactions and the inexorable link between strategy and process. Students had to develop strategy in a rapidly changing environment, with limited information and often unpredictable allies and adversaries. The model also demonstrated that strategy without process is pointless, whereas process without strategy is dangerous. 
Second, the simulation model is adaptable and relatively easy to emulate. The basic rules can be adjusted to emphasize different concepts and the content can be modified to reflect student interests and unfolding, real-world crises. Country teams can be added to accommodate more participants or diplomacy cells can be eliminated for smaller groups. The simulation can be incorporated into an introductory international relations or security studies course or implemented as a joint activity among smaller classes across subfields, with country-cell composition corresponding to substantive areas. The simulation also can be conducted as an extracurricular, department-wide activity or-as in our case-as part of the yearly programmatic activities of a center or institute.

Finally, the crisis-simulation format appealed to a much broader audience than a traditional security studies course. We clearly advertised that the simulation would develop skills useful in law and business as well as in politics and security; students who had never taken a political science course signed up (i.e., several finance and economics majors). Students also reported that a one-day simulation was a low-cost way for them to "try out" security studies. The crisis simulation thus allowed us to teach strategic thinking to a broad, interdisciplinary audience while also recruiting future students into the discipline.

\section{Challenges}

Moving forward, we are interested in developing a post-simulation assessment tool beyond the debriefing discussions. Indeed, incorporating this simulation into regular classes would require developing metrics to assess individual or team performance. This presents a challenging dilemma: in constructing a scoring system for performance, there is a risk incentivizing students to "game the game" rather than focus on the strategic processes at the crux of the simulation. In other words, grade-based assessment could undermine the pedagogical goals of the exercise. Ideally, we would want to score both the understanding of key concepts and the degree to which teams "acted strategically." The former could be achieved through a post-simulation quiz or survey, potentially taken weeks later to assess long-term learning. The latter, however, would require basing the evaluation on effectively deriving strategies that matched means to ends, conditional on the actions of other teams. It is a difficult task that we have yet to achieve.

We also encountered an unexpected challenge in repeating the crisis simulation because we opened participation to all students. Approximately $50 \%$ of participants in the second iteration of the simulation had participated in the Pakistan Crisis Simulation. Because of the knowledge they had gained and their mastery of the rules, the repeat players tended to dominate their teams, leading to feelings of marginalization among some new players. Moving forward, we think the best solution is to organize two different simulations that occur around the same time: one for new and one for repeat participants.

Finally, we want to find better ways to incorporate technology into future simulations. Students repeatedly noted the absence of the Internet and remarked that incorporating information technology would make the simulation seem more realistic. Social networking and cyber warfare also represent new ways to compete and cooperate strategically, and it would be interesting to see how they affected simulation learning and outcomes. However, we also are concerned that allowing students to use these technologies would undermine the artificial communication constraints we designed to simulate the struggles and irrationalities of large bureaucracies.

\section{NOTES}

1. See, e.g., DeNeve and Heppner 1997; Fox and Ronkowski 1997; Kolb 1984; Loggins 2009; Major and Palmer 2001; McCarthy and Anderson 2000; and Zaino and Mulligan 2009

2. More information about CISS and SEI is available at www.princeton.edu/ciss.

3. We incorporated 13 professionals into the country teams, including mid-career military officers from the Marine Corps Command and Staff College, West Point, and McGuire Air Force Base; representatives from several intelligence agencies; a former United Nations staffer; a Council on Foreign Relations fellow; and two corporate risk analysts.

4. As the chief designers of the simulation, we ran general logistics and managed the control cell. One or two student volunteers assumed each of the following tasks: tracking the materials and orders of an individual country team; updating the master map of troop deployments and other important geographically based actions; determining the actions of terrorists and other important actors and states not represented by the country teams; collecting orders and plans; and providing general logistical assistance. The entire control cell assisted with resolving orders at the end of each round.

\section{R E F E R E N C E S}

DeNeve, Kristina M., and Mary J. Heppner. 1997. "Role Play Simulations: The Assessment of an Active Learning Technique and Comparisons with Traditional Lectures." Innovative Higher Education 21 (Spring): 231-46.

Fox, Richard L., and Shirley A. Ronkowski. 1997. "Learning Styles of Political Science Students." PS: Political Science and Politics 30 (4): 732-7.

Kolb, David A. 1984. Experiential Learning: Experience as the Source of Learning and Development. Englewood Cliffs, NJ: Prentice Hall, Inc.

Loggins, Julie. 2009. "Simulating the Foreign Policy Decision-Making Process in the Undergraduate Classroom." PS: Political Science and Politics 42 (2): 401-7.

Major, Claire H., and Betsy Palmer. 2001. "Assessing the Effectiveness of ProblemBased Learning in Higher Education: Lessons from the Literature." Academic Exchange Quarterly 5 (Spring): 4-9.

McCarthy, J. Patrick, and Liam Anderson. 200o. "Active Learning Techniques Versus Traditional Teaching Styles: Two Experiments from History and Political Science." Innovative Higher Education 24 (Summer): 279-94.

Zaino, Jeanne S., and Tricia Mulligan. 2009. "Learning Opportunities in a Department-Wide Crisis Simulation: Bridging the International/National Divide." PS: Political Science and Politics 42 (3): 537-42. 